4. DeutschmanN, R.-Zur operativen Behandlung der Netzhautablosung, Klin. Mona.sbl.f. Augenheilk., Vol. IV, p. 364, 1906.

5. Elschig, A.-Ueber Glaskorperersatz, Ber. u. d. Versamml. d. deutsch Ophthal. Gesellsch., p. 514, 1911.

6. Rosentstein.-Die Heilwirkung der Glaskorperabsaugung bei inneren Augenkrankheiten, Klin. Monatsbl. f. Augenheilk., Vol. LXVII, p. 459. 1912.

7. Комото-Ueber Glaskorperwaschung, Klin. Monatsbl. f. Augenheilk., Vol. L, p. 265, 1912.

8. ERLANGER-Ein Fall von doppelseitiger Spatinfection nach Elliot's Trepanation 13/4 bzw 7 Jahr nach der operation, Klin. Monatsbl. f. Augenheilk., Vol. LXVII. p. 606, 1921.

9. Blatt-Ueber Punktion des Glaskorpers, nebst Beitrag Zum immuneschen und antibactericiden Verhalten desselben, Klin. Monatsbl. f. Augenheilk., Vol. LXVI, p. 889.

10.-Blaisch.-Zur Kasuistik der Glaskorperabsaugung, Klin. Monatsbl. f. Augenheilk., Vol. LXVIII, p. 831, 1922.

11. HambURG.-Punktionskuren ber chronisher Iridocyclitis, Ophthal. Ges. Wien., January 1, 1924 ; Klin. Monatsbl. f. Augenheilk., Vol. LXXII, p. 238,1924 .

12. Rоснат.-Ueber Glaskorperabsaugung nach zur Nedden bei Glaskorpertruburg, Klin. Monatsbl. f. Augenheilk., Vol. XXXIX, p. 239, 1925 ; Niederl. Ophthal. Ges., 1924.

13. Bliedung.-Vers Nordwest Augenarzte, Klin. Monatsbl. f. Augenheilk., Vol. XXVII, p. 775, 1924.

14. ZIRM.-Glaskorperabsaugung nach zur Nedden bei Glaskorpertrubung, Deutsch. Ophthal. Ges. i. d. Tschechoslouakei Aug., 2, 1925; Klin. Monatsbl. f. Augerheilk., Vol. LXXV, p. 772, 1925.

15. Bufili.-Die Indikationen der Extraktion des Glaskorpers, Klin. Monatsbl. f. Augenheilk., Vol. LXXIX, p. 282, 1927.

16. ZUR NEDDEN.- The Curative Value of Aspiration of the Vitreous, Arch. Ophthal., 57 : 109, March, 1928.

\title{
AUTOHAEMO-THERAPY IN HORDEOLOSIS*
}

BY

\author{
H. J. STERN \\ JERUSALEM
}

AUTOHAEMO-THERAPY seems to fall into oblivion. In this age of sulfonamides and penicillin it is regarded by many as a sort of mediaeval witchcraft. It has been tried and recommended in so many conditions, and the disappointment of bona-fide followers has frequently been so poignant, that it has fallen into discredit even in cases where its action is beneficial beyond doubt.

Autohaemo-therapy has been tried in asthma, serum sickness, urticaria; it has been employed in herpetiform dermatitis and

- Received for publication, July 8, 1947. 
pemphigus, in malaria and hemiplegia, and in practically all inflammatory eye conditions including, of course, trachoma and sympathetic ophthalmia. We find enthusiastic reports and thorough disappointment, tepid recommendation or no reference at all in many text-books.

This bewildering state of affairs is due to the fact that autohaemotherapy has been employed without discrimination in a multitude of conditions, with disappointing results in most of them.

There are some conditions, however, in which autohaemo-therapy is of undeniable value. Its beneficial effect on furunculosis is well known, and the same applies to hordeolosis, but it seems that the great number of alternative therapeutic agents, particularly sulfonamide and penicillin lately, have overshadowed its value and that it is but rarely used nowadays. It might be justified, therefore, to recommend once more this simple and effective therapy which has proved beneficial in so many cases.

A crop of styes, distributed over months sometimes, can be one of the most trying condition, both for patient and doctor. The number of remedies recommended for it shows that none of them is really satisfactory in all cases. To mention some: hot fomentations of course, and incision; ointments, paints, vaccines and autovaccines; yeast, vitamin $A$, tin salts, particularly stannoxyl, and lately the sulfonamides and penicillin. Ultra-violet, infra-red and even X-rays have been called to help. Autohaemo-therapy and autosero-therapy also belong to this incomplete list, and so does the vast number of preparations for parenteral protein shock therapy, beginning with milk.

There can be no doubt that all these therapeutic agents are useful. Local treatment combined with general medication is usually efficient, and, after all, even the most refractory hordeolosis yields eventually to a well directed therapy. But frequently it is taking up much time, it may even incapacitate the patient as in protein shock therapy, the preparation of auto-vaccines is a long, expensive procedure, and sulfonamides are potent but toxic drugs.

This is the reason why autohaemo-therapy seems to be highly recommendable. It is easily applied, keeps the patient on his job and is easily available. As to the results it is felt that they are as good as any-if not better. I have used autohaemo-therapy on a great number of unselected cases. If a patient tells me that he feels his third or fourth stye coming up he receives invariably an intramuscular injection of 10 c.c. of his own blood-and it is very rarely necessary to repeat this after a week or two. I had occasion to observe many of the patients thus treated over a long period and could satisfy myself that the cure was a definite one.

A few case histories shall illustrate this: 
(1) Cpl. W., aged 28 years, was an orderly in my hospital who reported sick in March, 1946, stating that he had suffered from styes for the last 5 months, that he actually was never without at least one or two during this time. He had received treatment on the usual lines by my predecessor which relieved the discomfort at the time and made the styes clear up quickly, but they kept recurring.

On examination he presented a mild chronic squamous blepharitis and one discharging as well as two young styes. He felt run down and listless but was otherwise healthy.

One injection of 10 c.c. of venous blood was made into the muscles of the thigh and the patient was instructed to stop all local treatment except hot fomentations. Two days later he reported back. The styes were going down and he felt subjectively better. A week later he reported again with a small stye on one lid just beginning. A second injection of 10 c.c. was made, the stye did not develop but became resorbed and from then on-he was observed for 6 more months-he had no further trouble. After the first injection he volunteered the information-brought forward hesitatingly and diffidently - that he felt physically better than ever before and that he was sure it was no imagination.

(2) Pt. T., aged 22. years. Reported with recurrent styes which had almost incapacitated him for the past 4 months. He had received routine treatment from the Medical Officer in his unit. On examination he presented one stye in the right upper lid which closed the eye and made it impossible for him to do his work. He received one injection of 10 c.c. of his own blood, and was told to stop local treatment except hot fomentations.

He reported back after one week. The stye had disappeared and he felt well. He was seen again after one month when no further styes had developed, and he wrote, after having been posted away, 5 months later that he had not had any more trouble with his eyes.

This list could be extended but would become monotonous. It may suffice to say that autohaemo-therapy has been used for many years, that all cases responded most satisfactorily, and that only rarely more than one injection had to be given.

It is not the purpose of this communication to speculate about the biological mechanism of this therapeutic procedure. It seems correct to assume that the blood, taken from the vein and injected into the muscle of the patient, has the properties of foreign blood perfectly adapted to the biological equilibrium of the receptor organism. It leads to a desensitization through stimulation of the reticulo-endothelial system. It is conceivable that specific antibodies are formed.

All this can, of course, be provoked by any protein shock therapy. 
It is emphasized, however, that auto-haemotherapy seems to be simpler, cheaper, less brutal and all the same equally effective as more elaborate procedures.

\section{ANNOTATION}

\section{Medical Imposition}

Devoted Austenians will remember among many felicitous sentences in her works, that in Mansfield Park, where it is stated that Lady ${ }^{\circ}$ Bertram was the happiest subject in the world for a little medical imposition. This leads one to offer some remarks on a very threadbare subject, viz., how far it is expedient to tell the whole truth to our patients. ?

A great deal depends on the type of patient and what is the matter with the eyes. A nervous sensitive patient of middle age, with a speck or two in her lenses and with full visual acuity, need not be told that she has incipient cataract. Should she mention the possibility of cataract developing we should explain that, while it is technically correct to say that she has some signs pointing that way, it will probably be many years before any serious diminution of vision will happen. One needs to be explicit over glaucoma cases, possible growths, and wounds of the eye. In the last case the sufferer will be well aware that all is not well with his eye; but an early glaucoma case with good vision and field will need careful handling. It is quite essential to get such a case to understand that the eye is in a bad way and it would be most improper to inculcate anything approaching a laissez faire attitude. Each surgeon must make up his own mind in each case. No explicit rules can be laid down for his guidance; but in general it may be stated that there are occasions where a little "imposition" may be not only desirable, but also permissible. We recall the case of a middle aged lady with some lenticular opacities and full vision, to whom we did not mention the word cataract. About a year later she called on us again and asked if, at her last visit, we had noted anything amiss with her eyes, as she had in the interval consulted someone else who told her she had cataract, and expressed surprise that no one had told her of it. Her vision was still $6 / 6$ and we said it was our opinion that the word cataract should not be mentioned in cases such as her's where no diminution of vision was noticeable. Some people ask to be told the whole truth, and occasionally others will implore us not to frighten them. 